\title{
Sequence analysis of the Bacillus subtilis chromosome region between the serA and $k d g$ loci cloned in a yeast artificial chromosome
}

\author{
Alexei Sorokin, Vasco Azevedo, $†$ Emmanuelle Zumstein, $\ddagger$ \\ Nathalie Galleron, S. Dusko Ehrlich and Pascale Serror \\ Author for correspondence: Alexei Sorokin. Tel: +331 34652533. Fax: + 33134652521 \\ e-mail: sorokine@biotec.jouy.inra.fr
}

Laboratoire de Génétique Microbienne, Institut National de la Recherche Agronomique, Domaine de Vilvert, 78352 Jouy en Josas cedex, France

\begin{abstract}
The standard strategies of genome sequencing based on $\lambda$-vector or cosmid libraries are only partially applicable to AT-rich Gram-positive bacteria because of the problem of instability of their chromosomal DNA in heterologous hosts like Escherichia coli. One complete collection of ordered clones known for such bacteria is that of Bacillus subtilis, established by using yeast artificial chromosomes (YACs). This paper reports the results of the direct use of one of the YAC clones from the above collection for the sequencing of the region cloned in it. The strategy applied consisted of the following: (i) construction of M13 banks of the partially purified YAC DNA and sequencing of 800 M13 clones chosen at random; (ii) directed selection of M13 clones to sequence by using marginal contig fragments as hybridization probes; (iii) direct sequencing of joining PCR fragments obtained by combinations of primers corresponding to the ends of representative contigs. The complete 104109 bp insert sequence of this YAC clone was thus established. The strategy used allowed us to avoid resequencing the two largest, previously sequenced, contigs (13695 and $20303 \mathrm{bp}$ ) of the YAC insert. We propose that the strategy used can be applied to the sequencing of the whole bacterial genome without intermediate cloning, as well as for larger inserts of eukaryotic origin cloned in YACs. Sequencing of the insert of the YAC clone 15-6B allowed us to establish the contiguous sequence of $127 \mathrm{~kb}$ from spollA to $\mathrm{kdg}$. The organization of the newly determined region is presented. Of the $138 \mathrm{ORFs}$ identified in the spollA-kdg region, 57 have no clear putative function from their homology to proteins in the databases.
\end{abstract}

Keywords: Bacillus subtilis genome, yeast artificial chromosomes, combinatorial PCR

\section{INTRODUCTION}

The genomes of the bacteria Haemopbilus influenzae and Mycoplasma genitalium have been completely sequenced (Fleishmann et al., 1995; Fraser et al., 1995) and several others, including Escherichia coli (Daniels et al., 1992),

\footnotetext{
+ Present address: Departamento de Biologia Geral., Instituto de Ciencias Biologicas, UFMG, Caixa Postal 486, Belo Horizonte, Brazil.

$\ddagger$ Present address: Laboratoire de l'Environment, INRA, Avenue des Etangs, 11100 Narbonne, France.

Abbreviations: contig, contiguous fragment; $Y A C$, yeast artificial chromosome.

The GenBank accession numbers for the sequences reported in this paper are L47648, L47709 and L47838.
}

Bacillus subtilis (Kunst et al., 1995; Ogasawara et al., 1995) and Mycobacterium leprae (Honoré et al., 1993), are currently being sequenced. The sequence of the genome of the lower eukaryote Saccharomyces cerevisiae is also expected to be available soon (Williams, 1995). In most cases, the sequencing strategies used have been based on the construction of ordered $\lambda$ - or cosmid-based vector collections in E. coli (Daniels et al., 1992; Glaser et al., 1993; Honoré et al., 1993; Oliver et al., 1992; Dujon et al., 1994; Wilson et al., 1994). The sequencing of the $H$. influenzae genome by a random approach was made feasible by the construction and use of a $\lambda$-based library (Fleichmann $e t$ al., 1995). In the case of the B. subtilis genome, and probably other AT-rich genomes of Gram-positive bacteria, many segments cannot be stably maintained in E. coli 
(Glaser et al., 1993; Ogasawara et al., 1994). In order to overcome this difficulty we have developed a sequencing strategy based on yeast artificial chromosomes (YACs; Burke et al., 1987). YACs have greatly facilitated genome mapping (Stalling et al., 1994), but until now had not been used for direct sequencing.

An ordered collection of segments of the $B$. subtilis genome in YACs has been constructed (Azevedo et al., 1993a). Here we report the sequencing of one of the YACs from the collection, designated 15-6B. The YAC carries a $104 \mathrm{~kb}$ insert from the region of the chromosome near $205^{\circ}$ which was assigned to our laboratory within the framework of the European $B$. subtilis genome project (Kunst \& Devine, 1991). The strategy used can presumably be applied to the megabase-scale YACs and to whole small genomes. The analysis of the nucleotide sequence is presented, focusing on the new genes for which a putative function can be postulated according to homologies with sequences in the databases. A putative transcriptional organization of the sequenced region is also proposed.

\section{METHODS}

Strains and growth conditions. Yeast cells containing artificial chromosomes were grown as described by Azevedo et al. (1993a). E. coli TG1 (K-12A(lac-pro) supE thi bsdR $\mathrm{F}^{\prime}{ }^{\text {[traD } 36}$ pro $A B$ laI $\left.{ }^{q} \Delta(\operatorname{lac} Z) \mathrm{M} 15\right)$ was used to make lawns on M13 selection plates and for growing phages in liquid medium. $E$.

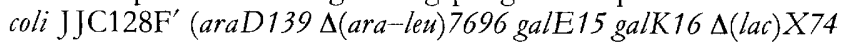
bsdR bsdM ${ }^{+} \operatorname{Str}^{\mathrm{R}} \mathrm{F}^{\prime}\left[\right.$ lacI $^{q} \Delta($ lacZ)M15 traD36]), which reproducibly gave efficiency of electroporation by M13 DNA approaching $5 \times 10^{8}$ p.f.u. $\mu \mathrm{g}^{-1}$, was used in cloning experiments. Electrocompetent cells of JJC128 $\mathrm{F}^{\prime}$ were prepared according to the protocol described by Dower $e t$ al. (1988) and stored at $-80^{\circ} \mathrm{C}$. Plasmid pCGS966 (Smith et al., 1990) was a gift from Dr D. Smith (Genome Therapeutics).

Isolation of YAC DNA. A derivative of the yeast strain 15-6B (Azevedo et al., 1993a), called rec9, was constructed by transforming $15-6 \mathrm{~B}$ with the EcoRI-NdeI fragment of pCGS966. Recombinants between the pCGS966 fragment and the left YAC15-6B arm, carrying the pBR322 replicon, were selected on a medium containing selective agents as described by Smith et al. (1990). A stable clone with an amplified (four copies) YAC, designated 15-6Brec9, was identified by direct screening of the yeast chromosomal DNA from resulting transformants. The identity of the insert in $15-6 \mathrm{Brec} 9$ with the corresponding B. subtilis chromosome tegion was verified by Southern hybridization. Plugs containing yeast chromosomes were made as described by Anand et al. (1989). Electrophoresis was performed in $1.2 \%(\mathrm{w} / \mathrm{v})$ agarose gels in $0.3 \times \mathrm{TBE}$ at $10 \mathrm{~V} \mathrm{~cm}^{-1}$ at $18^{\circ} \mathrm{C}(1 \times \mathrm{TBE}$ is $90 \mathrm{mM}$ Tris/borate, $2 \mathrm{mM}$ EDTA). The switching interval was from 0.3 to $6 \mathrm{~s}$ in forward migration and 0.1 to $2 \mathrm{~s}$ in reverse migration, for $20 \mathrm{~h}$. After separation, YACDNA was electroeluted in a dialysis membrane (Amicon) for $4 \mathrm{~h}$ at $10 \mathrm{~V} \mathrm{~cm}^{-1}$. The solution containing YAC DNA was then concentrated fivefold by butanol treatment and DNA was treated with phenol/chloroform before ethanol precipitation. This protocol allowed us to obtain about 5-10 $\mu \mathrm{g}$ YAC DNA from $500 \mathrm{ml}$ yeast cell culture.

M13 bank construction. The problem of constructing a representative and clean M13 library from purified YAC DNA was analysed recently (Vaudin et al., 1995). The authors suggested performing double purification of YAC by PFGE in order to avoid contamination by yeast DNA. We used another protocol, described below. Purified YAC DNA $(0 \cdot 5-10 \mu \mathrm{g})$ was partially digested by one of the following restriction enzymes: AluI, TaqI, HpaII or HinpI. The digested DNA was separated in agarose gel and segments between 500 and 1500 bp were purified as previously described (Sorokin et al., 1993). Purified DNA was ligated with $50 \mathrm{ng} S \mathrm{maI}-$ or $A c c \mathrm{I}$-cut and dephosphorylated M13mp19 vector in $20 \mu \mathrm{l}$ ligase buffer (Boehringer), precipitated by 2-propanol using tRNA or glycogen as a carrier, rinsed with $70 \%$ ethanol, dried, dissolved in deionized water and used for electroporation of $\mathrm{JJC} 128 \mathrm{~F}^{\prime}$ cells. The yield of phage plaques varied from $10^{5}$ to $10^{7}$ per $\mu \mathrm{g}$ M13 DNA, with a ratio of white to blue clones from 1 to 10 .

Selection of M13 clones for random and directed sequencing. White M13 plaques were propagated for $5 \mathrm{~h}$ in 48-well plates in

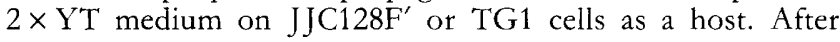
centrifugation on GPKR centrifuge (Beckman), $150 \mu \mathrm{l}$ aliquots of the phage supernatants were distributed into 96 -well plates by using a BIOMEC 1000 laboratory workstation (Beckman); $50 \mu \mathrm{l}$ aliquots of the same supernatants were used to prepare filters corresponding to the stock plates. The resulting filters were used to identify the M13 clones which carried YAC DNA inserts. For this purpose we used purified YAC DNA, labelled with ${ }^{32} \mathrm{P}$ by using a random-prime labelling kit (Boehringer), as a probe. The hybridized clones were randomly chosen for sequencing. The M13 clones sequenced during the directed sequencing step were selected by hybridization with the inserts of the phages corresponding to the ends of contiguous fragments (contigs) obtained during random sequencing. These inserts were amplified by PCR and pooled before labelling and hybridization. When only small gaps (estimated to be less than $500 \mathrm{bp}$ ) between contigs remained to be sequenced, the phage inserts used as probes were pooled in four different mixtures and only the M13 clones hybridizing with two of these mixtures were used for sequencing.

Sequencing. ssDNA of M13 phages was prepared as previously described (Sorokin et al., 1993). For reverse sequencing we used either M13 dsDNA prepared as described (Sorokin $e t$ al., 1995) or DNA generated by PCR using biotinylated primers and magnetic beads according to the supplier's protocol (Dynal). Direct and reverse PCR sequencing was performed by using an Applied Biosystems PRISM direct or reverse sequencing kit on a Perkin Elmer 9600 thermal cycler or a Catalyst station from Applied Biosystems. ssDNA sequencing using Sequenase was performed as previously described (Sorokin et al., 1993).

Oligonucleotide synthesis and PCR. Oligonucleotides were purchased from Eurogentec or synthesized on an Oligo 1000 DNA synthesizer (Beckman). PCR was performed by using M13 DNA or supernatants and B. subtilis or yeast chromosomal DNA in conditions previously described (Sorokin et al., 1993).

Computing. The xbap and xnip programs (Dear \& Staden, 1991) were used for gel assembling and consensus sequence analysis. The regions encoding proteins longer than 70 aa were further analysed for the presence of a sequence complementary to the $3^{\prime}$ end of 165 rRNA of $B$. subtilis, which is 3' UCUUUCCUCCACUAG... (McLaughlin et al., 1981) upstream of a potential start codon (AUG, UUG or GUG) considering that the largest ORF is the most probably functional. In cases of doubt, the statistical tests, namely codon usage or uneven positional base frequencies, offered by the xnip program were also applied. FASTA (Pearson \& Lipman, 1988) or BLAST (Altschul et al., 1990) algorithms available on the NCBI e-mail server were used for rapid homology searches. 
ORF nomenclature. In the framework of the B. subtilis Genome Project the names of the ORFs of the $l y s A-i l v A$ region should start with $y p$-. All the putative ORFs identified in this region were therefore named $y p x Z$, with $x$ assigning them to a putative operon or divergon proposed on the basis of locations of $\rho$-independent transcription terminators, and $Z$ distinguishing different ORFs in the same putative operon or divergon. The names of genes are used instead of, or along with, the $y p$ - names when the function of an ORF has been determined experimentally or can be proposed as a result of a homology search. Three sequences (Bruand et al., 1995; Sorokin et al., 1995; Bower et al., 1995; accession numbers U11289, U11687 and L38424) from the YAC15-6B region were released before the $y p$ - nomenclature had been chosen. The ORF names in these releases started with jo- instead of $y p$-. They have been therefore correspondingly renamed here.

Sequence accession numbers. The sequences corresponding to the YAC15-6B insert are available from GenBank under accession numbers L09228 (positions 1-13695 in 15-6B), L47648 (12396-37282), M80926 (37015-39348), M80245 (3934557318), L47709 (57126-80900) and L47838 (80824-104109). The entries L47648, L47709 and L47838 contain the newly determined sequence.

\section{RESULTS AND DISCUSSION}

\section{Direct sequencing of a YAC}

Sequencing strategy. Genomic sequencing generally comprises two main steps, one random and the other directed. The first is very efficient in the early stages of the project, and allows rapid generation of the bulk of the sequence, but it becomes inefficient later, since most of the randomly determined sequence is not novel. A switch to directed sequencing is therefore required to avoid an inordinate level of sequence redundancy. Our approach also used random and directed steps, carried out as follows.

Random sequencing was carried out on YAC segments subcloned in M13-derived vectors as described below. A number of contigs was thus established. Directed sequencing involved two phases. In the first, the clones from the M13 bank that allowed extension of the sequence were identified by hybridization, using as probes segments from the ends of the contigs. In the second, the contigs were ordered by combinatorial PCR and the gaps between them were closed by sequencing the appropriate PCR products.

Isolation of YAC DNA. To facilitate preparation of YAC DNA, we attempted to modify the copy number of YAC15-6B, using the approach described by Smith $e t$ al. (1990). For this purpose, pCGS966 was cleaved with EcoRI and $N d e I$ and introduced by transformation into a yeast strain carrying YAC15-6B, selecting for expression of the thymidine kinase gene. The chromosomes of the transformants, cultivated under conditions inducing Y AC amplification, were analysed by PFGE. Unexpectedly, $Y A C$ amplification was not induced in any of the clones. However, screening of clones grown on standard selective medium (Anand et al., 1989) revealed that one of them, designated rec?, contained about four copies of the YAC. The reasons for this increase in copy number are not understood. Rearrangements had not taken place in the
B. subtilis moiety of the amplified YAC, as judged by Southern hybridization (not shown), and DNA of this amplified YAC was therefore used for sequence analysis. The DNA was purified by PFGE and used for the construction of M13 libraries. Hybridization of these collections with purified YAC DNA indicated that $20-50 \%$ of the M13 clones contained a DNA insert from the YAC. Other M13 phages forming white plaques presumably contained yeast chromosomal DNA.

Random and directed sequencing step. About 800 M13 clones of the YAC15-6B library were randomly chosen for sequencing. This generated $\sim 90 \mathrm{~kb}$ of the consensus sequence, organized in 80 contigs, with a redundancy of $2 \cdot 8$. About $86 \%$ of the $104 \mathrm{~kb}$ YAC insert was thus sequenced. At this point we decided to switch to the direct sequencing. Two contiguous regions sequenced earlier (positions 1-13695 and 37015-57318; Sorokin et al., 1993; Roels et al., 1992; Henner et al., 1990) were excluded from further analysis. We first attempted to extend the sequence of 40 of the largest contigs. For this purpose inserts of $80 \mathrm{M} 13$ clones corresponding to the ends of the contigs were amplified by PCR, pooled in series of 20 and used as probes for hybridization with M13 clones that had not been previously sequenced. Sequencing of 300 positive clones extended the total contig length to $\sim 96 \mathrm{~kb}$, organized in 47 contigs. Iteration of this procedure revealed new hybridizing M13 clones, but did not allow us to extend the sequence significantly. This indicated that the appropriate M13 clones were absent or extremely rare in the M13 collection.

A similar conclusion was reached in attempts to identify the M13 clones carrying inserts that bridge two contigs and therefore hybridized with two different probe pools. Only five clones among 3000 tested joined the contigs. Given that the average distance between two contigs was $\sim 250 \mathrm{bp}(\sim 12 \mathrm{~kb}$ missing sequence distributed among 47 contigs), and the average M13 insert size was about $500 \mathrm{bp}$, many more bridging clones should have been identified. This supports the assumption that some chromosomal regions were severely under-represented in the M13 collection.

Combinatorial PCR. To complete the YAC sequence we decided to synthesize the missing regions by PCR, using B. subtilis chromosomal DNA as template. Forty oligonucleotides corresponding to the ends of the 20 longest contigs were used for this purpose. PCR products were obtained for all missing regions, varying in size from $0 \cdot 1$ to $6 \mathrm{~kb}$. They were used as probes for screening $2000 \mathrm{M} 13$ clones which had not been sequenced previously; 258 hybridizing clones were detected. Sequencing of the clones allowed us to make only eight additional contig joins, and several new contigs were formed. This result confirmed that the M13 bank was biased, and suggested that some $B$. subtilis regions cannot be cloned in E. coli even in short segments on M13 phages. This conclusion is supported by our failure to clone the PCR fragments in $E$. coli directly. The sequence of the YAC was therefore completed by primer walking over the PCR products.

The length of the novel sequence is $70111 \mathrm{bp}$. Sequence 

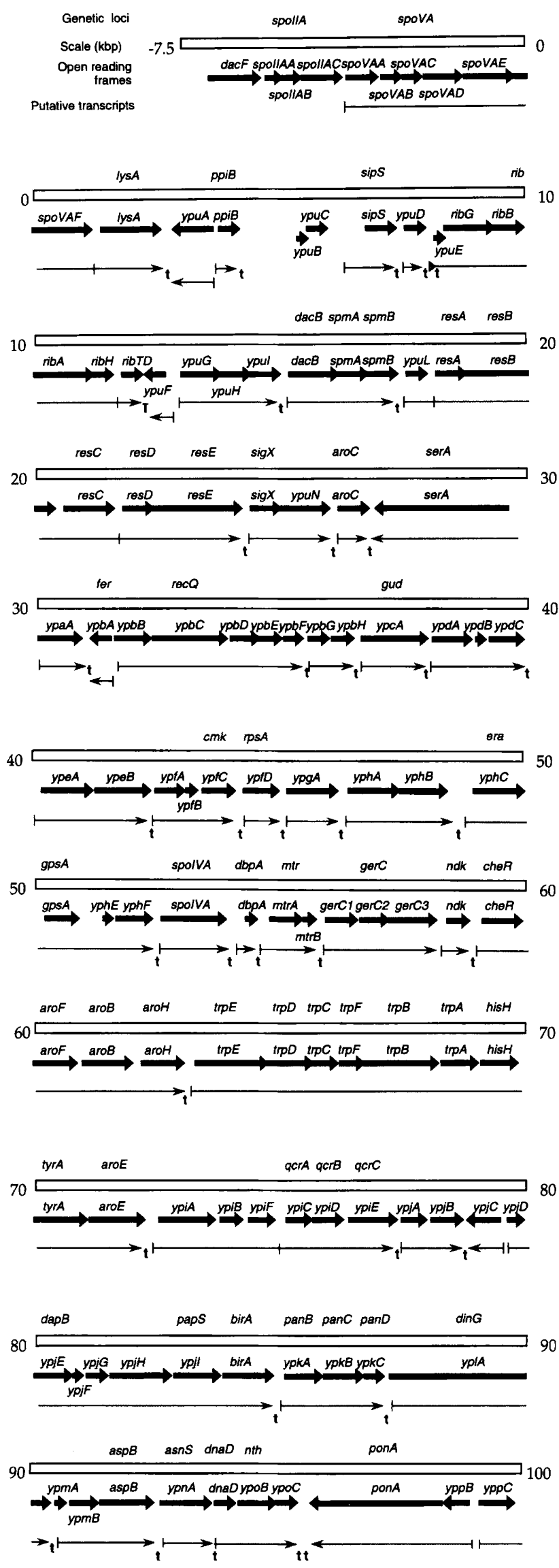
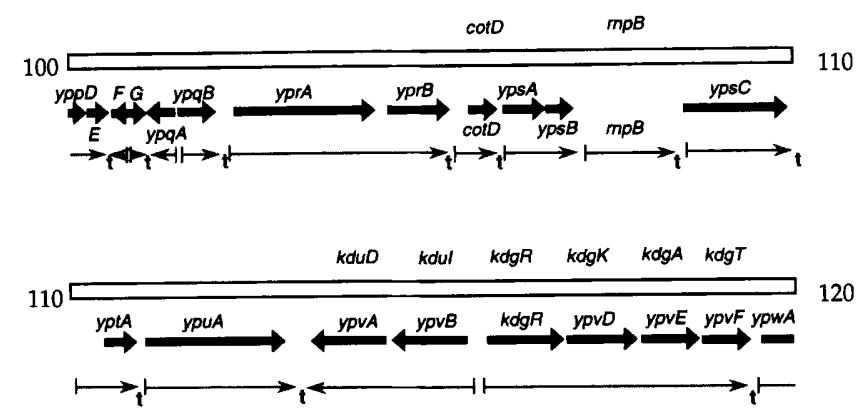

Fig. 1. Organization of the $B$. subtilis chromosome region between the spollA and $k d g$ loci. Thick arrows correspond to ORFs, detected by sequence analysis. Thin arrows show putative transcripts. Small 't's show the positions of stem-loop structures which may function as transcription terminators. The insert in YAC15-6B starts from the middle of ypul (position 14512 ) and ends in the middle of ypwA (position 118620). Nomenclature of ORFs is explained in the text. The regions from spollA to serA and from spolvA to aroE have been discussed elsewhere (Sorokin et al., 1993; Henner et al., 1990). The ORFs with unknown functions from the first publication are renamed as follows: orf $X 19$ to $y p u A$; orf $X 1$ to $y p u C$; orf $X 4$ to ypuD; orfX5 to ypuE; orfX6 to ypuF; orfX7 to ypuG; orfX8 to ypuH; orfX9 to ypul; orfX13 to ypuL; orf X21 to ypuN. The involvement of the previously found orfX11 and orfX12 in spore maturation, giving the names $s p m A$ and $s p m B$, was found recently (Popham et al., 1995). resABCDE were renamed from orf $\times 14-18$ after establishing the respiratory function of this operon (Sun et al., 1995). orfX20 was renamed sigX because this gene encodes a $\sigma$-factor (Lonetto et al., 1994). Other genes indicated above the scale bar encode the following: spo, sporulation genes; lysA, diaminopimelate decarboxylase; ppiB, peptidyl-prolyl isomerase; sips, signal peptidase; rib, riboflavin biosynthesis operon; dacB, D,D-carboxypeptidase; aroC, 3dehydroquinate dehydratase; serA, phosphoglycerate dehydrogenase; fer, ferredoxin; recQ, product homologous to the $E$. coli recQ gene product; gud, glutamate dehydrogenase; $c m k, C M P$ kinase; $r p s A, S 1$ ribosomal protein; era, product homologous to the $E$. coli era gene product; gpsA, glycerolphosphate dehydrogenase; $d b p A$, DNA-binding protein; $m t r$, 5-methyltryptophan resistance; gerC, germination deficiency; ndk, nucleotide diphosphate kinase; che $R_{\text {, }}$ chemotactic methyl transferase; aro, general pathway of aromatic amino acid biosynthesis; trp, tryptophan biosynthesis; his $H$, histidine biosynthesis; tyrA, tyrosine biosynthesis; qcr $A B C$, respiration $b f$-complex; $d a p B$, dihydropicolinate reductase; papS, poly(A) polymerase; birA, biotin biosynthesis regulation; pan, pantothenic acid biosynthesis; dinG, product homologous to the $E$. coli ding gene product; $a s p B$, aspartate aminotransferase; asnS, asparaginyl-tRNA synthetase; dnaD, a protein involved in the initiation of replication; $n$th endonuclease III; ponA, penicillin-binding protein 1; $\cot D_{\text {, }}$ spore-coat protein; rnpB, RNase P RNA component; $k d u, k d g$, enzymes of pectin and galacturonate catabolism. Numbering starts from the first base pair of the Sall site in the spoVAF gene, the same as for the entry with GenBank accession number L09228 (Sorokin et al., 1993).

redundancy is $\sim 11$, which is rather high due to the unsuccessful efforts to find M13 clones by hybridization with contig extremities. We anticipate that YAC sequencing could be accomplished with a redundancy of 5-6, by using combinatorial PCR directly after the random sequencing step. The complete $104109 \mathrm{bp}$ sequence of the YAC15-6B insert was established by joining 
the newly determined sequence to the known regions of 13695 and 20303 bp, mentioned above.

\section{Analysis of the sequenced region}

The sequenced region was analysed for the presence of ORFs encoding proteins larger than 70 amino acids and having an appropriate ribosome-binding site. The presence of structures characteristic of $\rho$-independent transcriptional terminators was also examined. The organization of the spoll $A-k d g$ region of the $B$. subtilis chromosome is presented in Fig. 1. The spoII $A-\operatorname{ser} A$ and spoIV $A$-aroE regions were described earlier (Sorokin $e t$ al., 1993; Roels et al., 1992; Henner et al., 1990). In the $\operatorname{ser} A-k d g T$ area, which is $90 \mathrm{~kb}$ long, 98 ORFs were detected. The average gene size is therefore $0.9 \mathrm{~kb}$, a figure very similar to that previously reported (Glaser $e t$ al., 1993; Ogasawara et al., 1994). For 89 ORFs, that is $91 \%$ of those detected, the direction of transcription is colinear with the replication fork movement. The $y p f A B C D, y p j D-b i r A$, asp $B-n t b$ and $p o n A$ regions were partially described in recent publications relevant to the functional characterization of the newly discovered genes (Sorokin et al., 1995; Bower et al., 1995; Bruand et al., 1995; Popham \& Setlow, 1995). The functional and structural characterization of the cot $D$ and $r r n P$ genes was also previously reported (Donovan et al., 1987; Reich $e t$ al., 1986). More detailed results of the database homology analysis are presented in Table 1 and discussed below.

\section{Genetic organization of the sequenced region}

serA and ypaA. The ser $A$ and $y p a A$ genes are organized in two divergent transcription units which share the regulatory region. $\operatorname{ser} A$ was partially sequenced before and shown to be involved in serine biosynthesis (Sorokin $e t$ al., 1993).

ypbA (fer) and ypbc. The $y p b A$ (fer) product is $79 \%$ identical to ferredoxin of Bacillus stearothermophilus, suggesting that $y p b A$ encodes a ferredoxin. It shares the regulatory region with the divergent $y p b B-y p b F$ operon. The protein encoded by $y p b C$ shares high homology with RecQ of $E$. coli, which is believed to be involved in the SOS response (Irino et al., 1986). Similarity of a region of these proteins (RecQ and YbpC) to RNA helicases of different species suggests that they contain an RNAbinding domain. The $y p b C$ product may be involved in the SOS response, as suggested by the presence of a potential promoter overlapping with a damage-induction associated SOB-operator site: GAAC-N ${ }_{4}$ GTTC (Cheo et al., 1991). Other genes of this operon may therefore also be involved in the stress response. Since the divergently transcribed $y p b A$ gene shares the regulatory region, it is conceivable that the stress response may be related to energy production or detoxification.

ypcA (gud). $y p c A$ (gud) is the second glutamate dehydrogenase gene of $B$. subtilis identified by sequencing. The first, called ipa-75d, was detected near $330^{\circ}$ (Glaser et al., 1993). In contrast to $i p a-75 d$, which was shown not to be expressed (Glaser et al., 1993), ypcA mRNA synthesis seems to be high and constitutive (P. Pujic, this laboratory, personal communication), indicating that: (i) YpcA is not the glutamate dehydrogenase studied by Kane et al. (1981), which has been shown to be repressed by carbohydrates and induced by glutamate, and (ii) YpcA might play a role in $\mathrm{NH}_{4}^{+}$utilization. However, glutamate synthase seems to be the only enzyme essential for $\mathrm{NH}_{4}^{+}$assimilation (Schreier, 1993).

ypfC (cmk) and ypfD (rpsA). The products of the genes $y p f C$ and $y p f D$ are homologous to the E. coli $m s s A$ and $r p s A$ gene products, respectively, the latter encoding the $\mathrm{S} 1$ ribosomal protein. The similar organization of this region in B. subtilis and E. coli led us to suggest that these genes are counterparts (Sorokin et al., 1995), although the function of the second gene in $B$. subtilis remains unclear. It has been shown recently that $m s s A$ of $E$. coli encodes cytidine monophosphate kinase and the gene was therefore renamed cmk (Fricke et al., 1995). It was reported that, in contrast to $E$. coli, $B$. subtilis contains only one pyrimidine ribonucleoside monophosphate kinase, synthesizing both UMP and CMP (Walch \& Ingraham, 1976). This is in good agreement with our finding that $y p f C$ is essential (Sorokin et al., 1995).

$\boldsymbol{y p g} \boldsymbol{A}$. This gene has the highest homology with the hypothetical protein ORF6 from the Erwinia berbicola carotenoid biosynthesis gene cluster. It also shares a homologous region with flavocytochromes $b$ and 2hydroxy-acid oxidases, shown to be essential for the activity of these proteins (Diêp Lê \& Lederer, 1991). However, several amino acids essential for the binding of flavin are absent in $y p g A$ and therefore no function for this gene can be suggested.

yphc (era). The product of this gene shows homology with the E. coli Era protein, an essential GTPase with a regulatory function. These proteins are structurally similar to RAS proteins of eukaryotes (Ahnn et al., 1986). In prokaryotes, they form a novel family of regulators, comprising at least five members (Ahnn et al., 1986; Trach \& Hoch, 1989; Yamashita et al., 1993; Ogasawara et al., 1994), but the function of none has yet been established. A distinctive feature of $\mathrm{YphC}$ from the proteins of this family is that it has two GTP-binding motifs (not shown). Studies of Era-depleted temperature-sensitive mutants of $E$. coli indicated that the protein is required for adaptation to thermal stress (Lerner \& Inoye, 1991) and cell division (Gollop \& March, 1991). The closest protein for which activities and tertiary structure are known in detail is EFTu (Weijland \& Parmeggiani, 1993).

yphD (gpsA). The protein encoded by $y p h D$ has high homology to the NADH-depenent glycerol-3-phosphate dehydrogenases. Mutants devoid of this activity, designated glyc, were isolated and studied in two laboratories (Oh et al., 1973; Freese \& Oh, 1974; Lindgren \& Rutberg, 1974). Three such mutations were mapped by Rutberg's group and high linkage was detected between $\operatorname{tr} p C$, bis and glyc markers by transformation. Taking into account the known distance between $\operatorname{tr} p C$ and bis $\mathrm{H}(5 \mathrm{~kb})$, the approximate distance between these markers might be estimated as $10 \mathrm{~kb}$, with the order glyc-trpC-hisH 
Table 1. Results of comparison of ORFs with sequences in the PIR protein data base

\begin{tabular}{|c|c|c|c|c|c|c|}
\hline ORF & $\begin{array}{l}\text { End-points } \\
\qquad(\mathrm{bp})^{*}\end{array}$ & $\begin{array}{l}\text { Size } \\
\text { (aa) }\end{array}$ & PIR entry & Description (size, aa) & $\begin{array}{l}\text { Homology } \\
\text { (FASTA score) }\end{array}$ & $\begin{array}{l}\text { Match } \\
(\%) \dagger\end{array}$ \\
\hline $\operatorname{ser} A$ & $14013-12436 c$ & 526 & deecpg & Phosphoglycerate dehydrogenase E. coli (410) & 324 & $30 \cdot 5(324)$ \\
\hline ypaA & $14510-15082$ & 191 & s02153 & $\begin{array}{l}\text { NADH dehydrogenase (ubiquinone) } \\
\text { mitochondrion Podospora anserina }(519)\end{array}$ & 130 & $28 \cdot 6(126)$ \\
\hline$y p b A($ fer $)$ & $15370-15122 \mathrm{c}$ & 83 & FEBSFF & Ferredoxin B. stearotbermopbilus (81) & 369 & $79 \cdot 0(81)$ \\
\hline \multirow[t]{2}{*}{$y p b C(\operatorname{rec} Q)$} & $16687-18177$ & 497 & bvecrq & recQ protein of E. coli $(610)$ & 788 & $40 \cdot 3(380)$ \\
\hline & & & s30278 & RNA helicase D. melanogaster (402) & 257 & $22 \cdot 0(369)$ \\
\hline$y p c A(g u d)$ & $21749-23029$ & 427 & a38168 & $\begin{array}{l}\text { Glutamate dehydrogenase Clostridium difficile } \\
(421)\end{array}$ & 1055 & $51 \cdot 6(419)$ \\
\hline \multirow[t]{2}{*}{$y p d A$} & $23138-24112$ & 325 & s18998 & Hypothetical protein B. licheniformis (122) & 454 & $77 \cdot 0(122)$ \\
\hline & & & s29117 & $\begin{array}{l}\text { Hypothetical protein Clostridium pasteurianum } \\
\text { (308) }\end{array}$ & 183 & $28 \cdot 4(296)$ \\
\hline$y p f C(\mathrm{cmk})$ & $28377-29051$ & 225 & s29160 & $\begin{array}{l}\text { Cytidine monophosphate kinase }(c m k) \text { E. coli } \\
(227)\end{array}$ & 465 & $44 \cdot 9(216)$ \\
\hline \multirow[t]{4}{*}{$y p f D(r p s, A)$} & $29284-30432$ & 383 & r3ec1 & Ribosomal protein S1 E. coli (557) & 662 & $39 \cdot 0(333)$ \\
\hline & & & $\mathrm{a} 26118$ & Polynucleotide phosphorylase E. coli (711) & 214 & $24 \cdot 2(236)$ \\
\hline & & & s13643 & PRP22 S. cerevisiae (1145) & 172 & $21 \cdot 2(255)$ \\
\hline & & & c36718 & $\begin{array}{l}\text { Pyruvate dehydrogenase E1 component } \\
\text { B. subilis (325) }\end{array}$ & 121 & $19 \cdot 2(281)$ \\
\hline$y p g A$ & $30856-31494$ & 213 & M87280‡ & $\begin{array}{l}\text { ORF6 of carotenoid biosynthesis cluster } \\
\text { Erwinia berbicola }(492)\end{array}$ & $7 \cdot 3 e^{-23}$ & $46 \cdot 0(92)$ \\
\hline$y p h C(e r a)$ & $33581-34891$ & 437 & rgecgt & GTP-binding protein Era E. coli (301) & 226 & $28 \cdot 2(226)$ \\
\hline$y p h D(g p s A)$ & $34909-35946$ & 345 & a26687 & $\begin{array}{l}\text { Glycerol-3-phosphate dehydrogenase } M u s \\
\text { musculus (349) }\end{array}$ & 335 & $31 \cdot 1(347)$ \\
\hline \multirow[t]{2}{*}{$y p i C(q c r A)$} & $60000-60503$ & 168 & a35580 & Rieske iron-sulfur protein Nostoc sp. (179) & 159 & $26 \cdot 2(145)$ \\
\hline & & & s16572 & $\begin{array}{l}\text { Plastoquinol-plastocyanin reductase } \\
\text { Synechocystis sp. (192) }\end{array}$ & 177 & $28 \cdot 3(145)$ \\
\hline$y p i D(q c r B)$ & $60505-61077$ & 191 & cbk16p & Cytochrome $b_{6}$ Chlorella protothecoides (215) & 404 & $42 \cdot 3(182)$ \\
\hline$y p i E(q \subset r C)$ & $61215-61982$ & 256 & wmsp17 & Cytochrome $b$ Spinacia oleracea (382) & 174 & $29 \cdot 1(117)$ \\
\hline$y p j A$ & $62129-62686$ & 186 & b31383 & $\begin{array}{l}\text { Hypothetical } 83 \mathrm{~K} \text { protein (brp locus) } \\
\text { Pseudomonas syringae ( } 731)\end{array}$ & 107 & $24 \cdot 7(81)$ \\
\hline$y p j E(\operatorname{dap} B)$ & $64950-65753$ & 268 & rdecpd & $\begin{array}{l}\text { Dihydrodipicolinate reductase Brevibacterium } \\
\text { lactofermentum (248) }\end{array}$ & 480 & $44 \cdot 9(205)$ \\
\hline \multirow[t]{4}{*}{ ypjH } & $66881-68014$ & 372 & a61112 & $\begin{array}{l}\text { Trans-acting transcription factor SPT14 } \\
\text { Saccbaromyces cerevisiae ( } 452)\end{array}$ & 288 & $21 \cdot 6(380)$ \\
\hline & & & a46217 & $\begin{array}{l}\text { Phosphatidylinositol glycan class A, PIG-A } \\
\text { Homo sapiens (484) }\end{array}$ & 186 & $16 \cdot 7(371)$ \\
\hline & & & s25526 & Sucrose-phosphate synthase Oryza sativa (452) & 132 & $24 \cdot 7(219)$ \\
\hline & & & s15296 & $\begin{array}{l}\text { Hypothetical protein Salmonella typhimurium } \\
(406)\end{array}$ & 166 & $25 \cdot 0(324)$ \\
\hline \multirow[t]{2}{*}{$y p j I($ pap $S)$} & $68019-69212$ & 398 & s11887 & pcnB Eschericbia coli (468) & 344 & $38 \cdot 9(221)$ \\
\hline & & & rnecta & tRNA nucleotidyltransferase E. coli (412) & 224 & $30 \cdot 4(224)$ \\
\hline $\operatorname{bir} A(\operatorname{bir} A)$ & $69213-70190$ & 326 & bvecbf & bir $A$ bifunctional protein $E$. coli $(321)$ & 342 & $26 \cdot 7(322)$ \\
\hline$y p k A(\operatorname{pan} B)$ & $70420-71253$ & 278 & P31057\$ & $\begin{array}{l}\text { Ketopantoate hydroxymethyltransferase E. coli } \\
\text { (264) }\end{array}$ & 630 & $47 \cdot 1(263)$ \\
\hline$y p k B($ panC $)$ & $71255-72115$ & 287 & P31663\$ & Pantothenate synthetase E. coli $(283)$ & 566 & $40 \cdot 8(282)$ \\
\hline$y p k C(\operatorname{pan} D)$ & $72117-72500$ & 128 & P31664\$ & Aspartate 1-decarboxylase E. coli (126) & 254 & $48 \cdot 3(116)$ \\
\hline$y p l A(\operatorname{din} G)$ & $72626-75421$ & 932 & a42717 & $\operatorname{din} G$ protein E. coli $(716)$ & 366 & $22 \cdot 4(696)$ \\
\hline $\operatorname{asp} B(\operatorname{asp} B)$ & $76251-77432$ & 394 & a38621 & Aspartate aminotransferase Bacillus sp. (392) & 1428 & $71 \cdot 3(387)$ \\
\hline$y p n A(a s n S)$ & $77576-78868$ & 431 & syecnt & Asparaginyl-tRNA synthetase E. coli (466) & 624 & $41 \cdot 1(265)$ \\
\hline$d n a D(d n a D)$ & $78961-79659$ & 233 & & No homologies & $<70$ & \\
\hline$y p o B(n t h)$ & $79696-80355$ & 220 & a32412 & Endonuclease III E. coli (211) & 439 & $46 \cdot 2(208)$ \\
\hline $\operatorname{pon} A(\operatorname{pon} A)$ & $83648-80904 c$ & 915 & s28033 & $\begin{array}{l}\text { Penicillin-binding protein 1a Streptococcus } \\
\text { pneumoniae ( } 719 \text { ) }\end{array}$ & 1083 & $39 \cdot 1(586)$ \\
\hline$y p p B$ & $84290-83670$ & 207 & $\mathrm{y} 23 \mathrm{k} \_$stror $\$$ & $\begin{array}{l}\text { Hypothetical } 23 \cdot 1 \mathrm{kD} \text { a protein in pon } A 5^{\prime} \\
\text { region Streptococcus oralis }(198)\end{array}$ & 477 & $50 \cdot 3(179)$ \\
\hline
\end{tabular}


Table 1. (cont.)

\begin{tabular}{|c|c|c|c|c|c|c|}
\hline ORF & $\begin{array}{l}\text { End-points } \\
\qquad(b p)^{*}\end{array}$ & $\begin{array}{l}\text { Size } \\
\text { (aa) }\end{array}$ & PIR entry & Description (size, aa) & $\begin{array}{l}\text { Homology } \\
\text { (FASTA score) }\end{array}$ & $\begin{array}{l}\text { Match } \\
(\%) \dagger\end{array}$ \\
\hline$y p q B$ & $87653-88159$ & 169 & wqeb3t & $\begin{array}{l}\text { Phosphotransferase system enzyme II, glucose } \\
\text { specific Salmonella typhimurium (530) }\end{array}$ & 357 & $40 \cdot 1(167)$ \\
\hline$y p r A$ & $88262-90511$ & 750 & s00986 & Initiation factor eIF-4AI Mus musculus (407) & 121 & $20 \cdot 0(140)$ \\
\hline $\cot D$ & $92081-92308$ & 76 & $\mathrm{~d} 27393$ & cotD protein B. subtilis $(75)$ & 418 & $100(75)$ \\
\hline уриА & $95679-97604$ & 642 & ding_ecoli $\S$ & ATP-dependent helicase DinG E. coli (716) & 145 & $33 \cdot 3(135)$ \\
\hline$y p v A(k d u D)$ & $98409-97645 c$ & 255 & s17711 & $\begin{array}{l}\text { Deoxygluconate oxidoreductase Erwinia } \\
\text { chrysantbemi }(253)\end{array}$ & 659 & $55 \cdot 0(251)$ \\
\hline$y p v B(k d u I)$ & $99238-98411 \mathrm{c}$ & 276 & s17710 & $\begin{array}{l}\text { Deoxyuronate isomerase Erwinia cbrysanthemi } \\
(278)\end{array}$ & 753 & $46 \cdot 0(278)$ \\
\hline$y p v C(k \operatorname{dg} R)$ & $99460-100479$ & 340 & s15318 & $\operatorname{ccp} A$ protein B. subtilis (334) & 425 & $27 \cdot 8(334)$ \\
\hline$y p v D(k d g K)$ & $100517-101491$ & 325 & ¡q0782 & Fructokinase Vibrio alginolyticus (307) & 251 & $27.5(287)$ \\
\hline$y p v E(k d g A)$ & $101493-102083$ & 197 & adecoq & $\begin{array}{l}\text { 2-Keto-4-hydroxyglutarate aldolase E. coli } \\
(213)\end{array}$ & 279 & $36 \cdot 4(165)$ \\
\hline$y p v F(k d g T)$ & $102128-103120$ & 331 & jq0113 & $\begin{array}{l}\text { 2-Keto-4-deoxygluconate permease Erwinia } \\
\text { chrysanthemi (398) }\end{array}$ & 894 & $51 \cdot 4(315)$ \\
\hline
\end{tabular}

* Positions in the YAC15-6B insert.

† The number of amino acids over which the match percentage was determined is shown in parentheses.

$\ddagger$ GenBank entry, homology detected by BLASTA search.

S SwissProt entry.

(Lindgren \& Rutberg, 1974). This matches well with our sequence data, supporting the possibility that $y p h D$ corresponds to the glyc gene. The updated name for this gene, proposed by Dr R. Rutberg, is $g \not s A$.

ypiCDE (qcrABC). The proteins encoded by ypiCDE are homologous to the Rieske iron-sulphur protein and the cytochrome $b$ subunit of the $b c_{1}$ or $b f$ respiration complexes. The $b f$ complex should contain cytochrome $b$, which consists of two subunits, and an $f$-type cytochrome (Trumpower, 1990). No cytochrome $f$-encoding gene was detected in the $y p i$ operon, nor elsewhere in the sequenced region. A more detailed characterization of these genes and the regulation of their transcription has been reported recently (Yu et al., 1995; Sun et al., 1995). We therefore used the names for these genes proposed by $\mathrm{Yu}$ et al. (1995).

ypje (dapB). This gene encodes a protein highly homologous to the $E$. coli dihydropicolinate reductase, an enzyme involved in the early steps of lysin biosynthesis. An enzyme with such activity was isolated from sporulating B. subtilis cells (Kimura, 1975). Since the protein isolated by Kimura (1975) is different from that encoded by $y p j E$, as judged by molecular mass $(18.5 \mathrm{kDa}$ and $29.5 \mathrm{kDa}$, respectively), it is possible that $B$. subtilis uses two enzymes for this pathway. This is in agreement with the finding of strikingly different dihydropicolinate reductases in Bacillus cereus and B. megaterium (Kimur \& Goto, 1977), leading to the notion of the existence of two different types of this enzyme in bacilli (Kimura et al., 1978).

ypji. The $y p j H$ gene product has homology with the yeast SPT14 and the human PIG-A proteins, which were recently shown to be involved in glycosylphosphatidylinositol (GPI) synthesis (Schönbächler et al., 1995). GPI is involved in anchoring of some proteins to the plasma membrane of eukaryotes. The presence of such a gene in $B$. subtilis suggests the existence of GPI-anchored proteins in this bacterium.

ypjl. About half of the protein encoded by $y p j I$ is highly homologous to the $E$. coli mRNA polyadenylase and tRNA nucleotidyltransferase. Multiple alignments of these proteins (not shown) indicate that it is more probable that they have a common motif, possibly involved in RNA-binding, rather than a common function.

ypkABC (panBDC). These three ORFs specify proteins highly homologous to the enzymes of the pantothenic acid biosynthesis pathway, encoded in $E$. coli by the panB, pan $C$ and pan $D$ genes. A functional pan $B$ gene was mapped near $60^{\circ}$ on the $B$. subtilis chromosome, next to panE, which also encodes an enzyme implicated in this pathway (Baigori et al., 1991).

ypla (dinG). The $22 \%$ homology of the $y p / A$ gene product to the DinG of E. coli suggests similar functions. The high molecular mass $(103 \mathrm{kDa})$ allowed us to find the corresponding product, having a $\mathrm{pI}$ of $6 \cdot 2$, to be detected on two-dimensional protein gels as a well-separated spot (Völker et al., 1994). This feature should allow easy monitoring of protein synthesis during induction of DNA damage, which might be a way of revealing its specific function.

aspB. The gene encoding aspartate aminotransferase was previously localized in this part of the $B$. subtilis chromosome by transformation (Hoch \& Mathews, 1972). The 


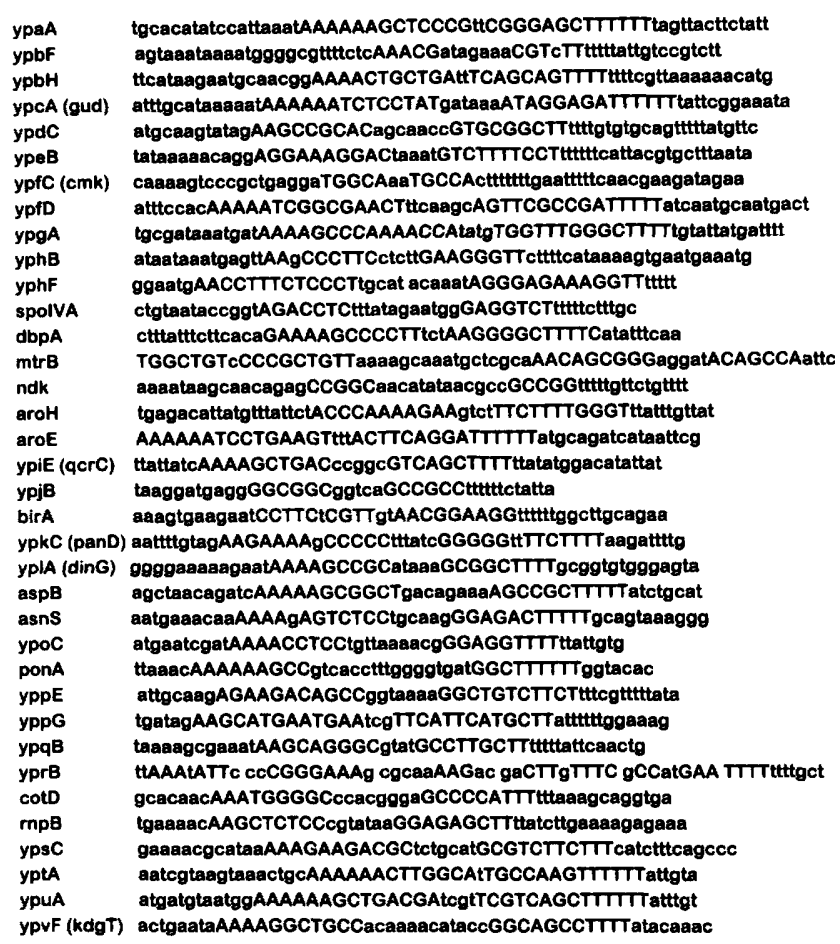

Fig. 2. Structure of putative $\rho$-independent transcription terminators. On the left are the names of ORFs preceding the putative terminators. Inverted repeats are indicated by capital letters.

very high similarity of its product to the structure of the enzyme from Bacillus sp. strongly suggested its function.

ypnA (asns). The $y p n A$ gene product is highly homologous to asparaginyl-tRNA-synthetase but its function needs to be experimentally tested. In the cases of tyrosyland threonine-tRNA-synthetase two active genes were found, having concerted regulation and complementing each other's activity (Glaser et al., 1990; Putzer et al., 1992; Grundy \& Henkin, 1993).

$\boldsymbol{y p q B}$. The protein encoded by this gene is homologous to the histidinyl domain of phosphotransferase system enzyme II of Salmonella typhimurium. According to the nomenclature suggested by Saier \& Reizer (1992), this domain is the first phosphorylation site of the IIA domain. This finding suggests similarities between the B. subtilis system and the glucose permease of $E$. coli or the sucrose permease of S. typhimurium.

yprA. Substantial homology of part of the YprA protein to the eukaryotic initiation factor eIF-4A from different species and also to an RNA-helicase of Drosophila melanogaster suggests that $y \operatorname{pr} A$ encodes an RNA-binding protein.

$\boldsymbol{r n p B}$. The $r n p B$ gene that encodes the RNA component of RNAse P was cloned and sequenced earlier (Reich $e t$ al., 1986).

ypvABCDEF ( $k d u D I-k d g R K A T)$. Several genes involved in pectin catabolism were isolated and sequenced from
Erwinia chrysanthemi (Condemine \& Robert-Baudouy, 1991; Hugouvieux-Cotte-Pattat \& Robert-Baudouy, 1994). The characterized genes from E. chrysantbemi also include the regulator of this system, kdgR (Reverchon et al., 1991). The relevant aldolase, the gene of which in Gram-negative bacteria is called $\mathrm{kgd} A$ or $e d a$, is one of the two enzymes of the Entner-Doudoroff pathway of gluconate assimilation, which does not play an essential role in Bacillus species (Goldman \& Blumenthal, 1963). Our homology search revealed six genes encoding a system for polygalacturonate catabolism, including aldolase and the putative regulator. Interestingly, the product of the regulatory gene has highest homology with the apparent catabolite repressor of $B$. subtilis $C \mathrm{cp} A$.

\section{Transcriptional features of the sequenced region}

The transcription signals which can be reliably predicted in bacteria from sequencing data are the $\rho$-indepenent transcription terminators (Daniels et al., 1992; Glaser et al., 1993). Identification of transcription terminators was shown to be useful for prediction of the transcription map which matches well with the experimentally defined one (Azevedo et al., 1993b). Fig. 2 lists the 36 stem-loop structures which may work as $\rho$-independent transcription terminators that were detected by analysis of the sequence of the region between the $\operatorname{ser} A$ gene and the $k d g$ operon. This list also contains terminators from the spoIV $A$-aro $E$ region, which was sequenced by others and was not discussed above, but is relevant to this study. Experimental studies of transcription of $y p f C-y p f D$ (Sorokin $e t$ al., 1995), spoIV A (Roels et al., 1992; Stevens et al., 1992), the $\operatorname{tr} p E$ regulatory region (Henner \& Yanofski, 1993), gcr ABC (Sun et al., 1996; Yu et al., 1995), cotD (Zheng \& Losick, 1990) and $r n p B$ (Reich et al., 1986) have already been reported. We can therefore consider the corresponding terminators as experimentally proven to be active. Some features of the promoter regions deduced from the sequence and which are potentially relevant to the regulation are discussed below.

ORFs $y p b C$ and $y p l A$ encode proteins that might be involved in the SOS response (see above). This implies that the corresponding promoters belong to the SOB regulon, which is characterized by the presence of the GAAC- $\mathrm{N}_{4}-$ GT'TC structure in the promoter regions (Cheo et al., 1991). Promoter structures and the SOB consensus sequence can easily be detected upstream of $y p b C$ and $y p l A$ (Fig. 3a, b). Although not so evident, a similar sequence exists also in the $y \operatorname{pr} A$ leader region (Fig. $3 c)$.

Surprisingly, the $y p j D$-bir $A$ operon encodes several genes having apparently different functions (see above, and Bower et al., 1995). This might be due to the fact that the biotin biosynthesis regulator, Bir A, is a negative regulator of biotin biosynthesis and at the same time a positive regulator of the $y p j D-\operatorname{bir} A$ operon. Thus, the biotin regulator might work as a switch between carboxylating enzymes containing biotin and lysine biosynthesis through tetrahydrodipicolinate. This is probably needed to regulate the concentration of oxaloacetate in the cells 
(a)

(b)

$\begin{array}{llllllllllllllllllll}\text { A } & V & L & N & D & Q & N & K & I & E & Q & M & \text { L } & G & N & E & P & A & R & T\end{array}$

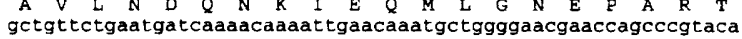
I $L$ *

attttgtagaagaaaagcccetttatcgggggtettcttt taagattttgagagtaaaa $\begin{array}{cc}-35 & -10 \\ \text { cggtttgecgetccatttecgtacaaaacGTGTAcactttegtegtatgcAAGATtg } & 87120\end{array}$ $\begin{array}{llllllllllllllllllllllll}M & N & K & Q & R & F & V & V & I & D & V & E & T & T & G\end{array}$

(c)

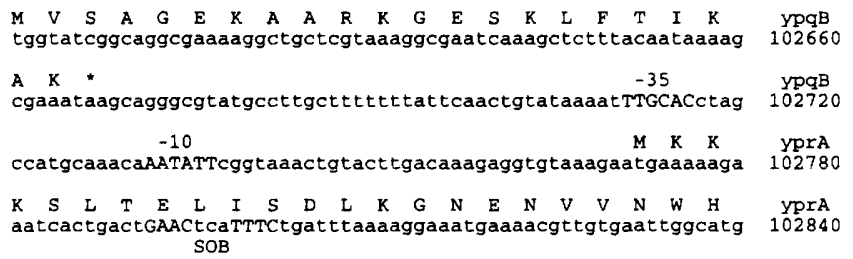

Fig. 3. Regulatory regions of the $y p b C(a), y p / A(b)$ and $y p r A(c)$ genes. Capital letters within the nucleotide sequence indicate the regions homologous to the $B$. subtilis SOB box (GAAC- $N_{4}$ GTTC) or the -35 (TTGACA) and -10 (TATAAT) boxes of the $\sigma^{A}$ promoters. Numbering as for Fig. 1.

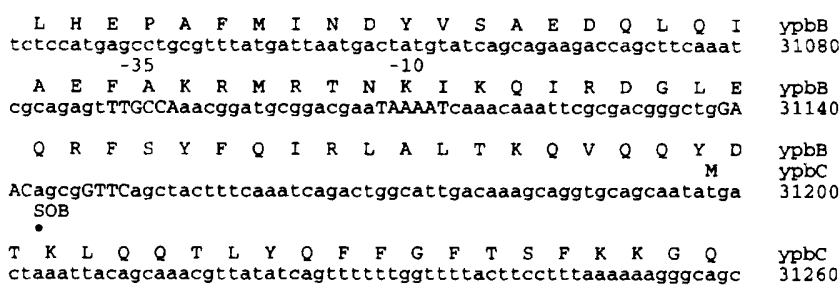
aggtgtccattttaatgaataagCAACggttCGTTGtatagatgtagagacaacaggga $\quad \begin{aligned} & \text { ypla } \\ & 87180\end{aligned}$

The two operons in the kdgRKAT-kduDI divergon resemble the classical lac operon case from Gram-negative bacteria (Jacob \& Monod, 1961). The putative regulator $\mathrm{KdgR}$ is highly homologous to the CcpA catabolite regulator of $B$. subtilis and therefore belongs to the LacI family of regulators. Preliminary data indicated that $\mathrm{KdgR}$ and CcpA are both negative regulators of transcription of the kdgRKAT operon (P. Pujic, personal communication). It would be interesting to identify the structural features which specify the difference in the interaction of $\mathrm{KdgR}$ and $\mathrm{CcpA}$ with the $k d g$ and other regulatory regions.

\section{Conclusions}

We have described the application of a sequencing strategy of a YAC insert by direct subcloning into M13 and by using random and directed selection of the templates to be sequenced. Since the $B$. subtilis genome contains sequences which are difficult or impossible to clone in $E$. coli, the direct sequencing of PCR products appears to be the most efficient directed sequencing approach. An optimal practical strategy can be proposed: (i) random sequencing, which becomes ineffective when the redundancy of accumulated raw sequence data approaches 3-4; and (ii) directed sequencing of PCR products corresponding to the gaps between contigs, ordered by combinatorial PCR strategies. This second step allows us to overcome the bias of the M13 libraries due to the 'unclonability' of some genome fragments in bacteriophage M13 (Glaser et al., 1993; Sorokin et al., 1993; Ogasawara et al., 1994). We do not see any obvious arguments against the application of this approach to the sequencing of a whole small genome (less than $10 \mathrm{Mb}$ ). Long-target PCR (Barnes, 1994; Cheng et al., 1994) greatly extends the possibilities for the use of combinatorial PCR. The feasibility of such an approach for the sequencing of a complete bacterial genome is supported by the data presented on YAC15-6B and by the sequencing of the $B$. subtilis genome regions contained in the YAC109 and YAC15-132 clones of the same collection, which is now being carried out in this laboratory. Our results also demonstrate that YAC-based collections of large genomes, for example the human genome, can be used directly for sequencing of regions of interest.

Fig. 4. Regulatory region of the $y p j D$ gene. Structures resembling $\sigma^{A}$ promoter regions (TTGACA and TATAAT) and homologous to the apparent BirA-operator site of $B$. sphaericus (AATGTGTTAACTTAAAAACTATAGTTGGTTAAC) are shown in capital letters. Numbering as for Fig. 1.

growing on metabolized sugars, since oxaloacetate produced by pyruvate carboxylation cannot enter rapidly into the citric acid cycle in such conditions (acetyl-CoA is needed) and must go to the biosynthesis of amino acids. An indirect support for this hypothesis might be that similar structures are present downstream of the Bacillus sphaericus biotin operon promoter and upstream of the potential $y p j D$-bir $A$ operon promoter (Fig. 4).

\section{ACKNOWLEDGEMENTS}

We thank C. Anagnostopoulos for his continuous interest and advice. We also thank P. Pujic for useful discussions and communicating unpublished data. The advice of Dr L. Bourgueleret and D. Catena (CEPH, Paris) on using the $x b a p$ program and of Dr Ph. Bessier, F. Samson and V. Biaudet on computing are highly appreciated. The part-time participation of students F. Bourguoin, G. Taylor and S. Darreau in the YAC15-6B sequencing cannot be overestimated. V.A. was a recipient of a Brazilian government fellowship. This work was supported, in part, by grants from GREG (décision 21) and EEC (BIO2-CT93-0272). 


\section{REFERENCES}

Ahnn, J., March, P. E., Takiff, H. E. \& Inouye, M. (1986). A GTPbinding protein of Escherichia coli has homology to yeast RAS proteins. Proc Natl Acad Sci US A 83, 8849-8853.

Altschul, S. F., Gish, W., Miller, W., Myers, E. W. \& Lipman, D. J. (1990). Basic local alignment search tool. J Mol Biol 215, 403-410. Anand, R., Villasante, A. \& Tyler-Smith, C. (1989). Construction of yeast artificial chromosome libraries with large inserts using fractionation by pulsed-field electrophoresis. Nucleic Acids Res 17, 3425-3433.

Azevedo, V., Alvarez, E., Zumstein, E., Damiani, G., Sgaramella, V., Ehrlich, S. D. \& Serror, P. (1993a). An ordered collection of Bacillus subtilis DNA segments cloned in yeast artificial chromosomes. Proc Natl Acad Sci US A 90, 6047-6051.

Azevedo, V., Sorokin, A. V., Ehrlich, S. D. \& Serror, P. (1993b). The transcriptional organisation of the Bacillus subtilis 168 chromosome region between the spoV $A F$ and ser $A$ genetic loci. Mol Microbiol 10, 397-405.

Baigori, M., Grau, R., Morbidoni, H. R. \& Mendoza, D. (1991). Isolation and characterisation of Bacillus subtilis mutants blocked in the synthesis of pantothenic acid. J Bacteriol 173, 4240-4242.

Barnes, W. M. (1994). PCR amplification of up to $35-k b$ DNA with high fidelity and high yield from $\lambda$ bacteriophage templates. Proc Natl Acad Sci US A 91, 2216-2220.

Bower, S., Perkins, J., Yocum, R. R., Serror, P., Sorokin, A., Rahaim, P., Howitt, C. L., Prasad, N., Ehrlich, S. D. \& Pero, J. (1995). Cloning and characterization of the Bacillus subtilis bir A gene encoding a repressor of the biotin operon. J Bacteriol 177, 2572-2575.

Bruand, C., Sorokin, A., Serror, P. \& Ehrlich, S. D. (1995). Nucleotide sequence of the Bacillus subtilis dnaD gene. Microbiology $141,321-322$.

Burke, D. T., Carle, G. F. \& Olson, M. V. (1987). Cloning of large segments of exogenous DNA into yeast by means of artificial chromosome vectors. Science 236, 806-812.

Condemine, G. \& Robert-Baudouy, J. (1991). Analysis of an Erwinia chrysanthemi gene cluster involved in pectin degradation. Mol Microbiol 5, 2191-2202.

Cheng, S., Fockler, C., Barnes, W. M. \& Higuchi, R. (1994). Effective amplification of long targets from cloned inserts and human genomic DNA. Proc Natl Acad Sci USA 91, 5695-5699.

Cheo, D. L., Bayles, K. W. \& Yasbin, R. E. (1991). Cloning and characterization of DNA damage-inducible promoter regions from Bacillus subtilis. J Bacteriol 173, 1696-1703.

Daniels, D. L., Plunkett, G., III, Burland, V. \& Blattner, F. R. (1992). Analysis of the Escherichia coli genome: DNA sequence of the region from 84.5 to 86.5 minutes. Science $257,771-778$.

Dear, S. \& Staden, R. (1991). A sequence assembly and editing program for efficient management of large projects. Nucleic Acids Res 19, 3907-3911.

Diêp Lê, K. H. \& Lederer, F. (1991). Amino acid sequence of long chain $\alpha$-hydroxy acid oxidase from rat kidney, a member of the family of FMN-dependent $\alpha$-hydroxy acid oxidizing enzymes. J Biol Chem 266, 20877-20881.

Donovan, W., Zheng, L., Sandman, K. \& Losick, R. (1987). Genes encoding spore coat polypeptides from Bacillus subtilis. J Mol Biol 196, 1-10

Dower, W. J., Miller, J. F. \& Ragsdale, C. W. (1988). High-efficiency transformation of E. coli by high-voltage electroporation. Nucleic Acids Res 16, 6127-6145.

Dujon, B., Alexandraki, D., André, B., Ansorge, W., Baladron, V.,
Ballesta, J. P., Banrevi, A., Bolle, P. A., Bolotin-Fukuhara, M., Bossier, P. et al. (1994). Complete DNA sequence of yeast chromosome XI. Nature 369, 371-378.

Fleishmann, R. D., Adams, M. D., White, O., and 37 other authors (1995). Whole-genome random sequencing and assembly of Haemophilus influenzae Rd. Science 269, 496-512.

Fraser, C. M., Gocayne, J. D., White, O., and 26 other authors (1995). The minimal gene complement of Mycoplasma genitalium. Science 270, 397-403.

Freese, E. B. \& Oh, Y. K. (1974). Adenosine $5^{\prime}$-triphosphate release and membrane collapse in glycerol-requiring mutants of Bacillus subtilis. J Bacteriol 120, 507-515.

Fricke, J., Neuhard, J., Kellin, R. A. \& Pedersen, S. (1995). The $\mathrm{cmk}$ gene encoding cytidine monophosphate kinase is located in the rps $A$ operon and is required for normal replication rate in Eschericbia coli. J Bacteriol 177, 517-523.

Glaser, P., Danchin, A., Kunst, F, Debarbouille, M., Vertes, A. \& Dedonder, R. (1990). A gene encoding a tyrosine-tRNA synthetase is located near sacS in Bacillus subtilis. DNA Seq 1, 251-261.

Glaser, P., Kunst, F., Arnaud, M., and 14 other authors (1993). Bacillus subtilis genome project: cloning and sequencing of the $97 \mathrm{~kb}$ region from $325^{\circ}$ to $333^{\circ}$. Mol Microbiol 10, 371-384.

Goldman, M. \& Blumenthal, H. J. (1963). Pathways of glucose in Bacillus subtilis. J Bacteriol 86, 303-311.

Gollop, N. \& March, P. E. (1991). A GTP-binding protein (Era) has an essential role in growth rate and cell cycle control in Escherichia coli. J Bacteriol 173, 2265-2270.

Grundy, F. J. \& Henkin, T. M. (1993). tRNA as a positive regulator of transcription antitermination in Bacillus subtilis. Cell 74, 475-482. Henner, D., Gollnick, P. \& Moir, A. (1990). Analysis of an 18 kilobasepair region of the Bacillus subtilis chromosome containing the mtr and gerC operons and the aro-trp-aro supraoperon. In Proceedings of the 6th International Symposium on Genetics of Industrial Microorganisms vol. 2, pp. 675-665.

Henner, D. \& Yanofski, Ch. (1993). Biosynthesis of aromatic amino acids. In Bacillus subtilis and Other Gram-positive Bacteria, pp. 269-280. Edited by A. L. Sonenshein, J. A. Hoch \& R. Losick. Washington, DC: American Society for Microbiology.

Hoch, J. \& Mathews, J. (1972). Genetic studies in Bacillus subtilis. In Spores $V$, pp. 113-116. Edited by H. O. Halvorson, R. Hanson \& L. L. Campbell. Washington, DC: American Society for Microbiology.

Honoré, N., Bergh, S., Chonteau, S., and 15 other authors (1993). Nucleotide sequence of the first cosmid from the Mycobacterium leprae genome project: structure and function of the rif-str regions. Mol Microbiol 7, 207-214.

Hugouvieux-Cotte-Pattat, N. \& Robert-Baudouy, J. (1994). Molecular analysis of the Erwinia chrysanthemi region containing the kdg $A$ and zwf genes. Mol Microbiol 11, 67-75.

Irino, N., Nakayama, K. \& Nakayama, H. (1986). The recQ gene of Escherichia coli K12: primary structure and evidence for SOS regulation. Mol Gen Genet 205, 298-304.

Jacob, F. \& Monod, J. (1961). Genetic regulatory mechanisms in the synthesis of proteins. $J$ Mol Biol 3, 318-356.

Kane, J. F., Wakim, J. \& Fisher, R. S. (1981). Regulation of glutamate dehydrogenase in Bacillus subtilis. I Bacteriol 148, 1002-1005.

Kimura, K. (1975). A new flavin enzyme catalysing the reduction of dihydropicolinate in sporulating Bacillus subtilis. I. Purification and properties. J Biochem 77, 405-413.

Kimura, K. \& Goto, T. (1977). Dihydrodipicolinate reductases from 
Bacillus cereus and Bacillus megaterium. I. Purification and properties. J Biochem 81, 1367-1373.

Kimura, K., Goto, T. \& Ujita, S. (1978). Two differentiatable types of dihydropicolinate reductases from sporulating bacilli. In Spores VII, pp. 308-311. Edited by G. Chambliss \& J. C. Vary. Washington, DC: American Society for Microbiology.

Kunst, F. \& Devine, K. (1991). The project of sequencing the entire Bacillus subtilis genome. Res Microbiol 142, 905-912.

Kunst, F., Vassarotti, A. \& Danchin, A. (1995). Organization of the European Bacillus subtilis genome sequencing project. Microbiology 141, 249-255.

Lerner, C. G. \& Inoye, M. (1991). Pleiotropic changes resulting from depletion of Era, an essential GTP-binding protein in Escbericbia coli. Mol Microbiol 5, 951-957.

Lindgren, V. \& Rutberg, L. (1974). Glycerol metabolism in Bacillus subtilis: gene-enzyme relationships. J Bacteriol 119, 431-442.

Lonetto, M. A., Brown, K. L., Rudd, K. E. \& Buttner, M. J. (1994). Analysis of the Streptomyces coelicolor sigE gene reveals the existence of a subfamily of eubacterial RNA polymerase $\sigma$ factors involved in the regulation of extracytoplasmic functions. Proc Natl Acad Sci US A 91, 7573-7577.

McLaughlin, J. R., Murray, C. L. \& Rabinowitz, J. C. (1981). Unique features in the ribosome-binding site sequence of the Grampositive Stapbylococcus aureus $\beta$-lactamase gene. $J$ Biol Chem 256, 11283-11291.

Ogasawara, N., Nakai, S. \& Yoshikawa, Y. (1994). Systematic sequencing of the 180 kilobase region of the Bacillus subtilis chromosome containing the replication origin. DNA Res 1, 1-6.

Ogasawara, N., Fujita, Y., Kobayashi, Y., Sadaie, Y., Tanaka, T., Takahashi, H., Yamane, K. \& Yoshikawa, H. (1995). Systematic sequencing of the Bacillus subtilis genome: progress report of the Japanese group. Microbiology 141, 257-259.

Oh, Y. K., Freese, E. B. \& Freese, E. (1973). Abnormal septation and inhibition of sporulation by accumulation of $\mathrm{L}-\alpha$-glycerophosphate in Bacillus subtilis mutants. J Bacteriol 113, 1034-1045.

Oliver, S. G., van der Aart, Q. J., Agostoni-Carbone, M. L., and 144 other authors (1992). The complete DNA sequence of yeast chromosome III. Nature 357, 38-46.

Pearson, W. R. \& Lipman, D. J. (1988). Improved tools for biological sequence comparison. Proc Natl Acad Sci USA 85, $2444-2448$.

Popham, D. L. \& Setlow, P. (1995). Cloning, nucleotide sequence and mutagenesis of the Bacillus subtilis pon $A$ operon, which codes for penicillin-binding protein (PBP) 1 and a PBP-related factor. J Bacteriol 177, 326-335.

Popham, D. L., Illades-Aniar, B. \& Setlow, P. (1995). The Bacillus subtilis dac $B$ gene, encoding penicillin-binding protein 5 , is part of a three-gene operon required for proper spore cortex synthesis and spore core dehydration. J Bacteriol 177, 4721-4729.

Putzer, H., Gendron, N. \& Grunberg-Manago, M. (1992). Coordinate expression of the two threonyl-tRNA synthetase genes in Bacillus subtilis: control by transcriptional antitermination involving a conserved regulatory sequence. $E M B O \quad J$ 11, 3117-3127.

Reich, C., Gardiner, K. J., Olsen, G. J., Pace, B., Marsh, T. L. \& Pace, N. R. (1986). The RNA component of the Bacillus subtilis RNase P. Sequence, activity and partial secondary structure. J Biol Chem 261, 7888-7893.

Reverchon, S., Nasser, W. \& Robert-Baudouy, J. (1991). Characterisation of kedgR, a gene of Erwinia chrysanthemi that regulates pectin degradation. Mol Microbiol 5, 2203-2216.
Roels, S., Driks, A. \& Losick, R. (1992). Characterisation of spoIV A a sporulation gene involved in coat morphogenesis in Bacillus subtilis. J Bacteriol 174, 575-585.

Saier, M. H., Jr \& Reizer, J. (1992). Proposed uniform nomenclature for the proteins and protein domains of the bacterial phosphoenolpyruvate:sugar phosphotransferase system. $J$ Bacteriol 174 , 1433-1438.

Schreier, H. J. (1993). Biosynthesis of glutamine and the assimilation of ammonia. In Bacillus subtilis and Otber Gram-positive Bacteria, pp. 281-298. Edited by A. L. Sonnenshein, J. A. Hoch \& R. Losick. Washington, DC: American Society for Microbiology.

Schönbächler, M., Horvath, A., Fassler, J. \& Riezman, H. (1995). The yeast SPT14 gene is homologous to the human PIG-A gene and is required for GPI anchor synthesis. EMBO J 14, 1637-1645.

Smith, D. R., Smyth, A. P. \& Moir, D. T. (1990). Amplification of large artificial chromosomes. Proc Natl Acad Sci USA 87, 8242-8246.

Sorokin, A. V., Zumstein, E., Azevedo, V., Ehrlich, S. D. \& Serror, P. (1993). The organisation of the Bacillus subtilis 168 chromosome region between the spol $A$ and ser $A$ genetic loci. Mol Microbiol 10, 385-395.

Sorokin, A., Serror, P., Pujic, P., Azevedo, V. \& Ehrlich, S. D. (1995). The Bacillus subtilis chromosome region encoding homologues of the Eschericbia coli mss $A$ and $r p s . A$ gene products. Microbiology 141, 311-319.

Stallings, R. L., Doggott, N. A., Ford, A., Langmire, J., Hildebrand, C. E., Deaven, L. L. \& Moyzis, R. K. (1994). Application of cosmid libraries in genome mapping and sequencing efforts. In Automated DNA Sequencing and Analysis, pp. 80-88. Edited by M. D. Adams, Ch. Fields \& J. C. Venter. New York: Academic Press.

Stevens, C. M., Daniel, R., Illing, N. \& Errington, J. (1992). Characterisation of a sporulation gene, spoIV $A$, involved in spore coat morphogenesis in Bacillus subtilis. J Bacteriol 174, 586-594.

Sun, G., Sharkova, E., Chesnut, R., Birkey, S., Duggan, M. F., Sorokin, A., Pujic, P., Ehrlich, S. D. \& Hulett, F. M. (1996). Regulators of aerobic and anaerobic respiration in Bacillus subtilis. J Bacteriol 178, 1374-1385.

Trach, K. \& Hoch, J. (1989). The Bacillus subtilis spoOB stage 0 sporulation operon encodes an esential GTP-binding protein. J Bacteriol 171, 1362-1371.

Trumpower, B. L. (1990). Cytochrome $b c_{1}$ complexes of microorganisms. Microbiol Rev 54, 101-129.

Vaudin, M., Roopra, A., Hillier, L., Brinkman, R., Sulston, J., Wilson, R. K. \& Waterston, R. H. (1995). The construction and analysis of M13 libraries prepared from YAC DNA. Nucleic Acids Res 23, 670-674.

Völker, U., Engelmann, S., Maul, B., Riethdorf, S., Voblker, A., Schmid, R., Mach, H. \& Hecker, M. (1994). Analysis of the induction of general stress proteins of Bacillus subtilis. Microbiology 140, $741-752$.

Walch, N. S. \& Ingraham, J. L. (1976). Pyrimidine monophosphokinase and the mode of RNA turnover in Bacillus subtilis. Arch Microbiol 110, 49-54.

Weijland, A. \& Parmeggiani, A. (1993). Toward a model for the interaction between elongation factor Tu and the ribosome. Science 259, 1311-1314.

Williams, N. (1995). Closing in on the complete yeast genome sequence. Science 268, 1560-1561.

Wilson, R., Ainscough, R., Anderson, K., and 52 other authors (1994). $2 \cdot 2 \mathrm{Mb}$ of contiguous nucleotide sequence from chromosome III of C. elegans. Nature 368, 32-38. 
Yamashita, Y., Takehara, T. \& Kuramotsu, H. K. (1993). Molecular characterization of a Streptococcus mutants mutant altered in environmental stress responses. J Bacteriol 175, 6220-6228.

Yu, J., Hederstedt, L. \& Piggot, P. (1995). The cytochrome $b c$ complex (menaquinone: cytochrome $c$ reductase) in Bacillus subtilis has a non-traditional subunit organisation. J Bacteriol 77, 6751-6760.
Zheng, L. \& Losick, R. (1990). Cascade regulation of spore coat gene expression in Bacillus subtilis. J Mol Biol 212, 645-660.

Received 16 January 1996; revised 29 February 1996; accepted 5 March 1996. 